\title{
Integritas Akademik dan Kecemasan Akademik dalam Menghadapi Ujian Nasional pada Siswa
}

\author{
Tyas Firmantyo, ${ }^{1}$ Asmadi Alsa ${ }^{2}$ \\ Universitas Gadjah Mada, Yogyakarta
}

\begin{abstract}
The objective of this research is to examine the correlation between academic anxiety and academic integrity on facing the state examination among twelfth grade students. This research was conducted in SMAN Y, involving 114 twelfth grade Mathematic and Natural Science students. Data was collected using Academic Anxiety scale and Academic Integrity scale and was analyzed using Spearman correlation technique because of abnormality of data on academic integrity. Result supported the hypothesis that there was a negative correlation between academic anxiety and academic integrity on facing the state examination $\left(r_{s}=-0,457 ; p<0,01\right)$. The determination coefficient of $r^{2}=0,209$, show the effective contribution of academic anxiety to academic integrity was $20,9 \%$.
\end{abstract}

Keywords: academic anxiety; academic integrity; State Examination

\begin{abstract}
Abstrak: Penelitian ini bertujuan untuk mengetahui apakah terdapat hubungan antara kecemasan akademik dan integritas akademik dalam menghadapi ujian nasional pada siswa kelas XII. Penelitian ini dilakukan di SMAN Y dengan melibatkan 114 siswa kelas XII jurusan MIA atau Matematika dan Ilmu Alam. Pengumpulan data dalam penelitian ini dilakukan dengan skala penelitian atau kuisioner Kecemasan Akademik dan Integritas Akademik. Analisis data dilakukan dengan menggunakan teknik korelasi Spearman Rank karena sebaran data yang tidak normal pada salah satu variabel penelitian. Hasil penelitian ini sejalan dengan hipotesis penelitian, yaitu bahwa terdapat hubungan negatif antara kecemasan akademik dan integritas akademik dalam menghadapi ujian nasional pada siswa di SMAN Y $\left(r_{s}=-0,457, \mathrm{p}<0,01\right)$. Koefisien determinasi, $\mathrm{r}^{2}=0,209$ menunjukkan sumbangan efektif kecemasan akademik terhadap integritas akademik siswa dalam menghadapi ujian nasional sebesar $20,8 \%$.
\end{abstract}

Kata Kunci: kecemasan akademik; integritas akademik; Ujian Nasional

Pendidikan memiliki peran yang strategis dalam meningkatkan kualitas sumber daya manusia untuk berfikir, merasa dan berperilaku. Hal ini sesuai tujuan pendidikan yang dikemukakan oleh Langeveld (1979) yaitu membawa manusia menuju taraf kedewasaan

Korespondensi mengenai isi artikel ini dapat dilakukan melalui email: ${ }^{1}$ tyas.firmantyo@mail.ugm.ac.id 2asmalsa@ugm.ac.id 


\section{Tyas Firmantyo, Asmadi Alsa}

yang mencakup bersikap tanggung jawab, memiliki kecakapan dalam mengambil keputusan, melakukan tindakan sesuai dengan norma dan nilai moral, membentuk self dan memiliki peran aktif di masyarakat. Winkel (1996) mengungkapkan bahwa pendidikan memiliki peran dalam mengembangkan tiga aspek dalam diri seorang individu, yaitu: kognitif, afektif, dan psikomotorik. Undang-Undang Republik Indonesia Nomor 20 Tahun 2003 tentang Sistem Pendidikan Nasional secara eksplisit menyebutkan bahwa pendidikan memiliki peran dalam mengembangkan potensi peserta didik dalam hal spiritual keagamaan, pengendalian diri, kepribadian, kecerdasan, akhlak mulia serta keterampilan lain.

Secara umum, terdapat dua aspek utama dalam diri manusia yang penting untuk dikembangkan oleh suatu sistem pendidikan, yaitu aspek moralitas dan kompetensi diri (Ancok \& Ramadhani, 2014). Aspek moralitas menekankan pada peningkatan akhlak mulia dan nilai moral dalam diri siswa serta seluruh praktisi pendidikan. Keberadaan nilai moral dan akhlak mulia dalam pelaksanaan pendidikan tidak bisa diabaikan karena akan menimbulkan kekacauan dan permasalahan dalam kemanusiaan (Luther, 2001). Pengabaian terhadap aspek moralitas juga menimbulkan perilaku kecurangan akademik, seperti contekan, yang berpotensi menghancurkan bangsa (Sugiarto, 2009). Sementara itu, aspek kompetensi menekankan pada peningkatan kemampuan dasar dan pengetahuan umum dalam diri siswa (Ancok \& Ramadhani, 2014). Pengetahuan umum memiliki kegunaan bagi siswa sehingga dapat berfungsi dengan baik di dalam masyarakat (Cronbach, 1963).

Suatu sistem pendidikan yang baik harus mengacu pada kedua aspek tersebut namun berbagai masalah yang timbul dalam proses pendidikan membuat tujuan pendidikan tidak terealisasikan secara sempurna. Di Indonesia, terdapat banyak permasalahan yang muncul terkait dengan pelaksanaan pendidikan. Salah satu permasalahan yang patut untuk dikaji lebih mendalam adalah permasalahan terkait pelaksanaan ujian nasional (UN) yang teridentifikasi kasus kecurangan akademik berupa perilaku contek-mencontek.

Perilaku contek-mencontek dalam mengerjakan UN dinilai sebagai sebuah perilaku yang menurunkan integritas akademik siswa. Menteri Pendidikan dan Kebudayaan (Mendikbud) Republik Indonesia, Anies Baswedan, menyatakan bahwa masih banyak kecurangan masif dalam mengerjakan UN di Indonesia. Hal ini terlihat dari Indeks Integritas Ujian Nasional (IIUN) yang cenderung rendah di SMA/SMK/MA di berbagai daerah di Indonesia. Dalam data IIUN 2015, Daerah Istimewa Yogyakarta menduduki peringkat tertinggi dari 34 provinsi di Indonesia dengan nilai IIUN sebesar 82,37\% (Kemendikbud, 2015). Sementara itu, daerah lain memiliki nilai IIUN yang cenderung rendah dengan tingkat 
Integritas Akademik dan Kecemasan Akademik dalam Menghadapi Ujian Nasional ....

kecurangan akademik lebih dari 20\%. Nilai IIUN bisa menentukan tingkat kejujuran seorang siswa dalam melaksanakan ujian nasional. Selain itu, IIUN juga bisa menjadi cerminan dari masyarakat secara umum terkait dengan sikap terhadap kecurangan dan kejujuran dalam proses pendidikan khususnya pelaksanaan UN (Tri, 2015).

Integritas akademik memiliki peran penting dalam kehidupan siswa. Anies Baswedan menyatakan bahwa perilaku korupsi dapat berawal dari tindakan contek-mencontek saat masa sekolah (Wicaksono \& Alfath, 2015). Perilaku kecurangan di kehidupan mendatang juga dinilai sebagai dampak dari sikap toleransi terhadap kecurangan akademik (Razek, 2014). Jiang, Emmerton \& McKauge (2013) menyatakan bahwa penurunan integritas akademik berpotensi memengaruhi kehidupan profesional siswa saat bekerja kelak. Becker et al. (dalam Ruto et al., 2011) mengungkapkan bahwa ketidakjujuran di lingkungan pekerjaan diawali dari ketidakjujuran di lingkungan akademik siswa. Dengan demikian, integritas akademik sangat diperlukan dalam pelaksanaan kegiatan-kegiatan akademik khususnya pelaksanaan UN.

Integritas akademik adalah bagian utama dari budaya akademik untuk menghindari kecurangan akademik (Kwong, Ng, Mark, \& Wong, 2013). Jiang et al. (2013) mengungkapkan bahwa integritas akademik merupakan sebuah ekspektasi dari nilai kejujuran, profesionalisme dan kepercayaan. The International Center of Academic Integrity (ICAI) menerbitkan sebuah buku berjudul "The Fundamental Values of Academic Integrity" mengungkapkan bahwa ada 6 nilai dasar dalam integritas akademik, yaitu: kejujuran, kepercayaan, kesetaraan/keadilan, penghargaan, tanggung jawab dan keberanian (ICAI, 2007). Integritas akademik adalah sikap individu dalam mempertahankan nilai yang benar secara konsisten di dalam lingkungan dan kegiatan akademik dengan mengedepankan aspek kejujuran, kepercayaan, kesetaraan/ keadilan, penghargaan, tanggung jawab dan keberanian.

Faktor-faktor yang memengaruhi integritas akademik seperti dijelaskaan oleh McCabe, Trevino \& Butterfield (1999) menemukan bahwa integritas akademik dipengaruhi faktor institusional/kontekstual dan sikap/personal. Salah satu faktor sikap/personal yang memengaruhi integritas akademik adalah kecemasan akademik. Onem (2010) dan Banga (2014) menyatakan bahwa kecemasan akademik muncul karena adanya kekhawatiran yang timbul atas kegagalan belajar dalam diri siswa. Secara lebih spesifik, siswa dapat merasakan kecemasan dalam menghadapi ujian (test anxiety) yang menghalangi siswa dalam mencapai potensi akademiknya (Rana \& Mahmood, 2010). Siswa dapat merasakan test anxiety baik sebelum atau saat melaksanakan ujian (Asghari, Kadir, Elias, \& Baba, 2012). Dengan demiki- 


\section{Tyas Firmantyo, Asmadi Alsa}

an, kecemasan akademik merupakan suatu jenis kecemasan yang berpotensi dirasakan oleh siswa dalam lingkungan akademik.

Putwain, Connors, dan Symes (2010) mengungkapkan bahwa kecemasan akademik akan memengaruhi 3 aspek dalam diri siswa, yaitu: kognitif, fisiologis-afektif dan perilaku. Rana \& Mahmood (2010) juga mengungkapkan bahwa kecemasan akan memengaruhi kognitif dan afektif siswa. Libert \& Morris (1967) menyatakan bahwa kecemasan akademik akan menimbulkan ketidaknyamanan fisik seperti rasa mual, pusing dan berkeringat. Pengaruh negatif kecemasan akademik pada diri siswa menimbulkan kecurangan akademik pada siswa sebagai bentuk perilaku harm avoidance siswa dalam kegiatan akademik khususnya pada situasi ujian (Kisamore, Stone, \& Jawahar, 2007).

\section{Metode}

Penelitian ini merupakan penelitian kuantitatif yang bertujuan untuk melihat hubungan antara kecemasan akademik dan integritas akademik siswa dalam menghadapi UN. Kecemasan akademik merupakan variabel bebas (independent variable) dan integritas akademik merupakan variabel terikat (dependent variable) dalam penelitian ini. Secara umum, variabel bebas adalah sebab dari terjadinya atau munculnya variabel tergantung (Kerlinger \& Lee, 2000). Dalam hal ini, kecemasan akademik akan memengaruhi kemunculan integritas akademik dalam diri siswa saat menghadapi UN.

Subjek dalam penelitian ini adalah siswa kelas XII di SMAN Y, Kabupaten Tulungagung yang akan melaksanakan UN. Sementara itu, jumlah subjek yang berhasil didapatkan dalam penelitian ini ialah sebanyak 114 siswa. Usia subjek penelitian berkisar antara 17 - 19 tahun dengan rata-rata usia subjek 18 tahun.

Penelitian ini menggunakan dua buah skala untuk mengukur masing-masing variabel penelitian, yaitu: Skala Integritas Akademik dan Skala Kecemasan Akademik. Kedua skala penelitian disusun berdasarkan landasan teori dari variabel yang digunakan dalam penelitian ini. Skala Integritas Akademik disusun berdasarkan aspek dan indikator integritas akademik yang dikemukakan oleh (ICAI, 2007). Sementara itu, Skala Kecemasan Akademik disusun berdasarkan aspek dan indikator kecemasan akademik yang dikemukakan oleh Rana \& Mahmood (2010), Libert \& Morris (1967) dan Putwain, Connors, \& Symes (2010).

Setelah dilakukan uji coba, Skala Integritas Akademik yang memiliki 60 item dianalisis dengan analisis korelasi Part-Whole Correlation dan diperoleh daya beda yang berkisar antara 0,236 hingga 0,572. Daya beda minimal yang diterapkan pada Skala Integritas Akademik 
Integritas Akademik dan Kecemasan Akademik dalam Menghadapi Ujian Nasional ....

adalah 0,250 sehingga ada beberapa item yang gugur. Dari hasil analisis terhadap Skala Integritas Akademik, jumlah item yang digugurkan adalah 27 item sehingga menyisakan 33 item yang sahih. Skor reliabilitas alat ukur Skala Integritas Akademik ialah sebesar 0,910 sehingga skala penelitian ini dinilai baik (Weiner \& Stewart, 1984).

Sementara itu, Skala Kecemasan Akademik memiliki 27 item yang sahih dengan skor reliabilitas sebesar 0,920 setelah dilakukan uji coba. Skala Kecemasan Akademik memiliki 30 item awal yang dianalisis menggunakan Part Whole Correlation sehingga diperoleh daya beda yang berkisar antara 0,049 hingga 0,745. Daya beda minimal yang diterapkan pada Skala Kecemasan Akademik ialah 0,300 sehingga ada 3 item yang gugur.

Kedua alat ukur penelitian memiliki total item sebanyak 60 item. Kedua alat ukur dinilai memiliki validitas dan reliabilitas yang baik sehingga dapat dipergunakan untuk mengukur variabel penelitian. Dalam penelitian ini, kedua skala penelitian mengukur variabel dengan cara yang berbanding terbalik. Pada penelitian ini metode analisis data yang digunakan adalah metode korelasional yang menggunakan analisis statistik Spearman.

\section{Hasil}

Data yang didapatkan dari penelitian ini digambarkan melalui Tabel 1. tentang gambaran umum skor variabel-variabel penelitian. Selain itu, gambaran umum skor variabel-variabel penelitian menujukkan keadaan subjek penelitian yang menjadi sasaran penelitian.

Tabel 1.

Gambaran umum skor variabel-variabel penelitian

\begin{tabular}{ccccccccc}
\hline \multirow{2}{*}{ Variabel } & \multicolumn{4}{c}{ Skor Hipotetik } & \multicolumn{5}{c}{ Skor Empirik } \\
& $\mathbf{X}_{\min }$ & $\mathbf{X}_{\max }$ & $\mathbf{M e a n}_{(\boldsymbol{\mu})}$ & $\mathbf{S D}(\mathbf{\sigma})$ & $\mathbf{X}_{\min }$ & $\boldsymbol{X}_{\max }$ & Mean (x) & SD (s) \\
\hline $\begin{array}{c}\text { Integritas } \\
\text { Akademik }\end{array}$ & 33 & 165 & 99 & 22 & 73 & 138 & 110,0789 & 12,425 \\
$\begin{array}{c}\text { Kecemasan } \\
\text { Akademik }\end{array}$ & 27 & 135 & 81 & 18 & 38 & 106 & 64,5526 & 13,227 \\
\hline
\end{tabular}

Keterangan:

$\mathrm{X}_{\min }$ : Skor Minimum; $\mathrm{X}_{\max }$ : Skor Maksimum; Mean: Rata-rata; SD: Standar deviasi

Dari Tabel 1 diketahui bahwa ada perbedaan skor hipotetik dan skor empirik variabelvariabel penelitian. Pada skor variabel integritas akademik, mean empirik memiliki skor lebih tinggi daripada mean hipotetik. Hal ini menunjukkan bahwa integritas akademik siswa kelas XII di SMAN Y cenderung lebih tinggi. Selain itu, skor standar deviasi empirik variabel 


\section{Tyas Firmantyo, Asmadi Alsa}

integritas akademik lebih rendah daripada standar deviasi hipotetik. Hal ini menunjukkan adanya kesamaan sikap pada siswa kelas XII di SMAN Y terkait dengan integritas akademik. Sebaliknya, variabel kecemasan akademik memiliki skor mean empirik yang lebih rendah daripada mean hipotetik. Hal ini menunjukkan bahwa siswa kelas XII di SMAN Y memiliki kecenderungan merasakan kecemasan yang rendah selama menghadapi UN. Selain itu, skor standar deviasi empirik variabel kecemasan akademik juga menunjukkan nilai yang lebih rendah daripada skor standar deviasi hipotetiknya. Dengan demikian, subjek penelitian memiliki sikap yang cenderung sama saat menanggapi kecemasan akademik dalam menghadapi UN.

Dalam penelitian ini dilakukan pula uji normalitas sebaran terhadap subjek penelitian menggunakan one-sample Kolmogorov Smirnov Test untuk melihat normalitas sebaran dan menentukan analisis statistik yang akan digunakan. Standar yang digunakan dalam menentukan normalitas sebaran data adalah: jika $\mathrm{p}>0,050$ maka sebaran data penelitian dikatakan normal. Sebaliknya, jika nilai $\mathrm{p}<0,050$ maka sebaran data dikatakan tidak normal. Hasil uji normalitas sebaran terhadap kedua variabel penelitian dapat dilihat dalam Tabel 2.

Tabel 2

Rangkuman hasil uji normalitas sebaran

\begin{tabular}{ccccccc}
\hline No. & Variabel & Mean & SD & $\mathbf{Z}_{\text {KS }}$ & p & Keterangan \\
\hline 1 & Integritas Akademik & 110,0789 & 12,425 & 0,087 & 0,035 & Tidak Normal \\
2 & Kecemasan Akademik & 64,5526 & 13,227 & 0,066 & 0,200 & Normal \\
\hline
\end{tabular}

Keterangan:

Mean: Rata-rata; SD: Standar deviasi; ZKs: Z score; p: Nilai signifikansi

Dalam Tabel 2 dijelaskan bahwa kedua variabel memiliki normalitas sebaran data yang tidak sama. Variabel integritas akademik memiliki nilai $Z_{K S}=0,087$ dengan $p=0,035(p$ $<0,050)$ sehingga dikatakan bahwa data variabel integritas akademik tidak normal. Sebaliknya, variabel kecemasan akademik memiliki $Z_{K S}=0,066$ dengan $p=0,200(p>0,050)$ sehingga dikatakan bahwa data variabel kecemasan akademik memiliki sebaran data yang normal. Akibat perbedaan nilai normalitas ini maka analisis statistik yang digunakan dalam penelitian ini adalah analisis statistik non-parametrik khususnya Spearman.

Uji hipotesis dalam penelitian ini menggunakan analisis statistik Spearman untuk melihat dinamika hubungan antara variabel kecemasan akademik dan integritas akademik. Hipotesis yang diajukan dalam penelitian ini adalah terdapat hubungan negatif antara kecemasan akademik dan integritas akademik pada siswa dalam menghadapi ujian 
Integritas Akademik dan Kecemasan Akademik dalam Menghadapi Ujian Nasional ....

nasional. Pengujian terhadap hipotesis penelitian dilakukan dengan teknik korelasi Spearman. Hasil analisis korelasi menunjukkan bahwa korelasi antara variabel kecemasan akademik dan integritas akademik memiliki koefisien korelasi $\left(r_{s}\right)=-0,457$, dan $p=0,000(p$ $<0,010)$. Berdasarkan hasil tersebut maka dapat disimpulkan bahwa terdapat hubungan negatif antara kecemasan akademik dan integritas akademik siswa dalam menghadapi UN. Dengan demikian, hipotesis dalam penelitian ini dinyatakan diterima.

Koefisien determinasi hubungan kedua variabel penelitian adalah sebesar $\mathrm{r}^{2}=0,209$. Koefisien determinasi menunjukkan sumbangan efektif variabel independen dalam memberi pengaruh terhadap variabel dependen. Dengan demikian, sumbangan efektif kecemasan akademik terhadap integritas akademik adalah sebesar 20,9\%. Hal ini menunjukkan bahwa ada 79,1\% sumbangan dari faktor lain terhadap integritas akademik siswa dalam menghadapi UN.

\section{Diskusi}

Hasil penelitian merujuk hasil penelitian dalam Tabel menunjukkan bahwa terdapat hubungan negatif antara kecemasan akademik dan integritas akademik pada siswa dalam menghadapi UN. Hal ini menunjukkan bahwa semakin tinggi kecemasan akademik yang dirasakan oleh siswa maka semakin rendah pula integritas akademik yang dimiliki oleh siswa. Sebaliknya, semakin rendah kecemasan akademik yang dirasakan oleh siswa maka semakin tinggi pula integritas akademik yang dimiliki oleh siswa. Kecenderungan ini muncul ketika siswa berada dalam keadaan tertekan seperti dalam persiapan menghadapi UN.

Dalam penelitian lain, kecemasan akademik dinilai memiliki hubungan negatif dengan prestasi belajar siswa (Rana \& Mahmood, 2010). Selain itu, kecemasan akademik yang tinggi juga akan menimbulkan menurunan motivasi belajar yang dimiliki oleh siswa dalam kegiatan akademik. Keadaan seperti ini akan berdampak buruk pada prestasi belajar yang diraih oleh siswa. Siswa akan cenderung mencari solusi paling cepat untuk mengatasi kecemasan akademik yang dirasakannya, salah satunya dengan perilaku mencontek yang menurunkan integritas akademik dalam dirinya.

Penurunan integritas akademik dalam diri siswa disebabkan juga oleh berbagai faktor lain selain kecemasan akademik. McCabe et al. (1999)menyatakan bahwa ada dua faktor utama yang memengaruhi integritas akademik siswa dalam kegiatan akademik di sekolah, khususnya dalam situasi ujian. Kedua faktor tersebut dinilai memiliki peran penting dalam 
dinamika integritas akademik yang dimiliki siswa. Namun demikian, faktor yang berkaitan dengan attitudes/personal factors merupakan faktor yang lebih berpengaruh jika dinilai dari lingkungan internal siswa. Siswa memiliki berbagai macam sikap atas kegiatan akademik yang dijalaninya, salah satunya adalah respon cemas yang menimbulkan pengaruh terhadap berbagai hal. Kecemasan merupakan salah satu emosi negatif yang dimunculkan siswa saat berada dalam kegiatan atau lingkunngan akademik.

Roberts \& Hai-Jew (2009) menyatakan bahwa siswa memerlukan sebuah pengendalian diri dan pengendalian emosi untuk menghadapi munculnya emosi negatif atas lingkungan akademiknya. Pengendalian emosi yang baik membuat siswa dapat mengontrol perilakunya dan berpotensi untuk menahan perilaku negatif yang mungkin dapat dilakukan siswa. Dengan demikian, siswa diperkirakan dapat mempertahankan integritas akademiknya dalam menghadapi UN bila siswa mampu mengendalikan diri dan emosinya saat menhadapi UN.

Selain faktor internal, penurunan integritas akademik juga disebabkan oleh faktor eksternal salah satunya budaya dalam lingkungan akademik. Salah satu budaya dalam lingkungan akademik yang memiliki peran dalam dinamika integritas akademik adalah sistem pendidikan. Sistem pendidikan yang berpotensi menurunkan integritas akademik perlu diperbaiki. Penurunan integritas akademik dalam diri siswa merupakan sebuah fenomena yang membawa dampak yang tidak baik bagi kemajuan bangsa misalnya kemrosotan moral anak didik, potensi munculnya perilaku korupsi di masa depan dan lain sebagainya. Selain itu penurunan integritas akademik membawa dampak bagi kehidupan profesional atau pekerjaan siswa di masa depannya kelak (Razek, 2014). Oleh sebab itu, sistem pendidikan yang lebih baik sangat diperlukan sehingga tidak memunculkan kecemasan akademik yang berpotensi menurunkan integritas akademik.

Pelaksanaan metode pembelajaran yang menggunakan pendekatan humanistik merupakan salah satu contohnya. Dalam metode humanistik, siswa menjadi individu yang merasa dihargai sehingga memiliki self-efficacy yang baik. Peningkatan self-efficacy ini menurunkan kecemasan dan ketakutan selama proses pendidikan berlangsung (Barrows, Dunn, \& Lloyd, 2013). Selain itu, Kisamore et al. (2007) menyatakan bahwa metode pembelajaran active learning bagi siswa merupakan salah satu cara meningkatkan self-efficacy siswa. Peningkatan self-efficacy mengurangi timbulnya kecemasan dan meningkatkan integritas akademik siswa dalam belajar. 
Integritas Akademik dan Kecemasan Akademik dalam Menghadapi Ujian Nasional ....

Buruknya sistem pendidikan merupakan sebuah masalah yang perlu diselesaikan oleh segenap lapisan masyarakat. Hasil penelitian ini dapat dijadikan salah satu acuan evaluasi sistem pendidikan Indonesia. Selain itu, penelitian ini juga bisa dijadikan salah satu dasar pertimbangan dalam menyusun sistem evaluasi belajar bagi siswa sehingga memiliki kemungkinan kecil untuk menyebabkan kecemasan akademik yang tinggi. Harapan dari menurunnya kecemasan akademik siswa adalah adanya peningkatan integritas akademik dalam diri siswa sehingga siswa bisa menjalani proses pendidikan dengan lebih baik.

\section{Simpulan}

Berdasarkan hasil dan pembahasan terhadap penelitian ini, maka dapat ditarik sebuah kesimpulan penelitian bahwa terdapat hubungan yang negatif dan signifikan $\left(r_{s}=\right.$ 0,457; $\mathrm{p}<0,010$ ) antara kecemasan akademik dan integritas akademik siswa kelas XII dalam menghadapi ujian nasional. Selain itu, hal ini juga menunjukkan bahwa hipotesis penelitian ini dinyatakan diterima. Sumbangan efektif kecemasan akademik terhadap integritas akademik pada diri siswa dalam menghadapi ujian nasional adalah sebesar 20,9\%. Hal ini berarti ada sumbangan 79,1\% dari faktor-faktor lain, di luar kecemasan akademik, yang juga memiliki hubungan dan memberi pengaruh terhadap keberadaan integritas akademik pada siswa.

Saran

Berdasarkan hasil dan kesimpulan penelitian di bagian sebelumnya, peneliti memberikan beberapa saran kepada beberapa pihak terkait dengan tujuan penelitian. Saran ini merupakan sebuah rekomendasi terkait dengan penggunaan data dan hasil penelitian ini sehingga dapat dimanfaatkan dengan optimal. Adapun saran-saran tersebut adalah sebagai berikut:

Hasil penelitian ini dapat dijadikan sebuah acuan untuk mengevaluasi proses pembelajaran di SMAN Y, khususnya bagi kelas XII, yang hendak menghadapi ujian nasional. Upaya-upaya untuk meningkatkan integritas akademik dapat dimulai dari tindakan penurunan kecemasan akademik pada siswa sehingga siswa dapat belajar dengan lebih tenang dan tidak tertekan.

Selain itu bagi peneliti berikutnya yang hendak meneliti variabel yang sama yaitu kecemasan akademik dan integritas akademik diharapkan memperluas lokasi penelitian ke sekolah-sekolah lain untuk mengetahui apakah hubungan antara kecemasan akademik dan 


\section{Tyas Firmantyo, Asmadi Alsa}

integritas akademik juga terjadi di sekolah lain. Hasil penelitian ini menunjukkan bahwa kecemasan akademik memiliki peran terhadap integritas akademik. Namun demikian ada faktor lain yang juga memengaruhi integritas akademik siswa. Peneliti berikutnya diharapkan dapat mempertimbangkan faktor lain untuk dianalisis perannya terhadap integritas akademik sehingga bisa diketahui dengan lebih komprehensif mengenai faktorfaktor yang memiliki peran terhadap integritas akademik siswa, misalnya usia, jenis kelamin, tekanan dan lain sebagainya.

\section{Daftar Pustaka}

Ancok, D., \& Ramadhani, N. (2014). Pemimpin sekolah yang inspirasional: Aplikasi teori psikologi kepemimpinan dalam praktek manajemen pendidikan. Jakarta: Titian Foundation.

Asghari, A., Kadir, R. A., Elias, H., \& Baba, M. (2012). Test anxiety and its related concepts: a brief review, 22(3), 3-7.

Banga, C. L. (2014). Academic anxiety among high school students in relation to gender and type of family. Shodh Sanchayan, 5(1), 1-7.

Barrows, J., Dunn, S., \& Lloyd, C. A. (2013). Anxiety, self-Efficacy, and college exam grades. Universal Journal of Educational Research, 1(3), 204-208. https://doi.org/ 10.13189/ ujer.2013.010310

Cronbach, L. C. (1963). Educational psychology: Second Edition. United States of America: Harcourt, Brace \& World, Inc.

ICAI. (2007). The fundamental values of academic integrity. Clemson: Clemson University Press.

Jiang, H., Emmerton, L., \& McKauge, L. (2013). Academic integrity and plagiarism: a review of the influences and risk situations for health students. Higher Education Research $\mathcal{E}$ Development. Retrieved from http://www.tandfonline. com/doi/abs/10.1080/ 07294360.2012 .687362

Kemendikbud. (2015). Laporan konferensi pers 18 Mei 2015: Indeks integritas dan rata-rata nilai ujian nasional tahun 2015 per kabupaten/kota. Jakarta: Kementerian Pendidikan dan Kebudayaan Republik Indonesia.

Kerlinger, F. N., \& Lee, H. B. (2000). Foundations of behavioral research: 4th Edition. Orlando: Harcourt College Publishers.

Kisamore, J. L., Stone, T. H., \& Jawahar, I. M. (2007). Academic integrity: The relationship between individual and situational factors on misconduct contemplations. Journal of Business Ethics, 75(4), 381-394. https:/ / doi.org/10.1007/s10551-006-9260-9

Kwong, T., Ng, H.-M., Mark, K.-P., \& Wong, E. (2013). Students' and faculty's perception of academic integrity in Hong Kong. Campus-Wide Information Systems. https://doi.org/10.1108/10650741011087766 
Langeveld, M. J., Martinus, J. (1979). Beknopte theoretische pedagogiek [Book]. Retrieved December 14, 2016, from http:/ / dspace.library.uu.nl/handle/1874/7452

Liebert, R. M., \& Morris, L. W. (1967). Cognitive and emotional components of test anxiety: a distinction and some initial data. Psychological Reports, 20(3), 975-978. https:// doi.org/10.2466/pr0.1967.20.3.975

Luther, M. M. (2001). Values and ethics in school education. New Delhi: Tata McGraw-Hill Publishing Company Limited.

McCabe, D. L., Trevino, L. K., \& Butterfield, K. D. (1999). Academic integrity in honor code and non-honor code environments: A qualitative investigation on JSTOR. Retrieved December 14, 2016, from http://www.jstor.org/stable/2649128

Onem, E. (2010). The relationship among state-trait anxiety, foreign language anxiety and test anxiety in an EFL setting. TÖMER-Language Journal, 148, 17-36.

Putwain, Connors, \& Symes. (2010). Journal of Scholastic Inquiry Behavioral Sciences, 1(1). Retrieved fromhttps://issuu.com/csiresearch/docs/journal_of_scholastic_inquirybehav?reader $3=1$

Rana, R. A., \& Mahmood, N. (2010). The relationship between test anxiety and academic achievement. Retrieved from https:/ / papers.ssrn.com/ abstract=2362291

Razek, N. (2014). Academic integrity: a saudi student perspective. Proquest, 18(1), 143-154.

Robert, C. J., \& Hai-Jew, S. (2009). Issues of academic integrity: an online course for students addressing academic dishonesty. Journal of Online Learning and Teaching, 5 (2), 182196.

Sugiarto, R. (2009). 55 Kebiasaan kecil yang menghancurkan bangsa. Yogyakarta: Pinus Book.

Tri. (2015, Mei). Suara Karya: Kesra. Suara Karya. Retrieved from www.suarakarya.id/ 2015/05/18/terungkap-kecurangan-masif-dalam-pelaksanaan-un-sma.html

Weiner, E. A., \& Stewart, B. J. (1984). Assessing individuals: Psychological and educational tests and measurements. Boston: Little Brown.

Winkel, W. S. (1996). Psikologi pengajaran. Jakarta: Grasindo. 